\title{
Handbook of Florida Agricultural Laws: Crops and Products ${ }^{1}$
}

Michael T. Olexa, lan Alperstein, and Joseph Fischer ${ }^{2}$

\section{Preface}

This handbook is designed to provide an accurate, current, and authoritative summary of the principal Florida laws that directly or indirectly relate to agriculture. It provides a basic overview of the many rights and responsibilities that farmers and farm land owners have under Florida laws. Many readers may value this handbook because it informs them about these rights and responsibilities, and it provides them with good contacts for more detailed information. However, the reader should be aware that because the laws, administrative rulings, and court decisions on which this handbook is based are subject to constant revision, portions of this handbook could become outdated at any time. Many details of cited laws are also left out due to space limitations. 


\section{A Brief Note on Florida Laws and Rule Making}

The Florida laws described in this handbook were passed by the state legislature and have become valid state laws. The appropriate state agency then wrote specific rules based on each law. These rules are what the state agencies use to enforce the law. For most laws in this handbook, that agency is the Department of Agriculture and Consumer Services (DACS). Florida legislated laws, also called statutes, are organized into chapters. A chapter is divided even further into specific statutes. For example, Chapter 601 (Florida Citrus Code) contains dozens of sections covering topics ranging from marketing, inspection standards, and processing to prohibitions on the use of certain chemicals for citrus fruit. Other chapters may deal with a narrower subject and have far fewer sections. As noted above, the specific rules for each of these sections are written by a designated state agency, and generally go into greater detail. You can view the Florida Statutes online at http://www.flsenate.gov/statutes.

\section{Introduction}

This handbook can be used to learn which Florida laws apply to a particular agricultural project or subject, and to find the name, address, and telephone number of a state office that can provide more specific information or services. Created for readers with no prior experience in the law, the handbook is designed as a necessary first step in recognizing which agricultural activities merit special attention because of their implications to agriculture. The handbook also provides an introduction to the crucial agencies and statutes which govern agricultural law.

The online handbook is divided into a Table of Contents, Index, and six fact sheets. The Table of Contents gives general and specific areas of Florida laws related to agriculture and the number of the fact sheet where that topic can be found. The six fact sheets are as follows: FE114, General Agriculture-Related Laws; FE115, Animal Husbandry; FE116, Crops and Products; FE117, Related Non-Crop or Product Agricultural Topics; FE118, Environmental and Conservation Regulations; and FE119, Taxation and Property Rights Related to Agricultural Land. The user can find the specific laws by using either the Table of Contents (FE113) or the Index (FE122).

Below is an example of using the handbook if your area of interest is farming exotic animals such as ostriches.

To use the Table of Contents:

1. Find "Animal Husbandry" in the Table of Contents (FE113).

2. Within the Animal Husbandry area locate "Livestock-Exotic Animals". Follow the link to FE115: Animal Husbandry.

3. In FE115, read the "General Descriptions" and "Related References, Details, and Exceptions" columns for both laws under "Livestock-Exotic Animals". Determine if the information answers the questions or if more information is needed.

4. If the user wants more information regarding the general farming or inspection and slaughter of an exotic animal (e.g., ostriches), locate the appropriate state office telephone number and address. The primary contact agency information is listed at the end of the fact sheet, along with abbreviation information.

To use the Index:

Look up "ostriches" in the Index (FE122). The index leads the reader to the location for information about the culture and inspection/slaughter of ostriches. Follow steps 3 and 4 above to find the contact information.

\section{Division of the Tables}

The table in each fact sheet has five columns of information. The first column, "Statute / Law (description)," either provides the law's name or a general description when no name is available. The second column, "Florida Statute Number", lists either a chapter number when an entire chapter relates to a particular topic, a range of sections, or a single 
specific section. At times, a single chapter number may have many more laws than a range. For example, sections 593.101 to 593.117 cover a narrower field, the control of cotton boll weevil, than the larger Chapter 601 on citrus fruit. The chapter and section number in all columns are presented without the typical abbreviations or symbols.

Columns 3 and 4 provide brief descriptions and related references, details, and exceptions. This information is highly condensed. As such, not all information is provided. The authors have attempted to include the most relevant aspects of each listed law. Additional information can be obtained by contacting the offices noted in the final column, "Primary Contact Agencies." As noted above, the primary contact information is listed at the end of the fact sheet. The reader will find that the state and federal agencies are unquestionably the best targets for specific questions, as they are in close touch with both the formal and practical considerations of the areas that they regulate.

This publication can be improved with your ideas and suggestions. Comments regarding any areas which may have been omitted, but deserve inclusion, are particularly valuable. Reader feedback is a necessary ingredient to complete any successful future editions. Please send your comments or suggestions to:

Michael T. Olexa

Director, Agricultural Law Center

Food and Resource Economics Department

Post Office Box 110240

University of Florida

Gainesville, FL 32611-0240

Fax (352) 392-9898 


\begin{tabular}{|c|c|c|c|c|}
\hline \multicolumn{5}{|c|}{ III. Florida Agricultural Laws: Crops and Products } \\
\hline $\begin{array}{l}\text { Statute / Law } \\
\text { (description) }\end{array}$ & $\begin{array}{l}\text { Florida } \\
\text { Statute } \\
\text { Number }\end{array}$ & General Description & $\begin{array}{l}\text { Related References, Details, } \\
\text { and Exceptions }\end{array}$ & $\begin{array}{l}\text { Primary } \\
\text { Contact } \\
\text { Agencies }\end{array}$ \\
\hline \multicolumn{5}{|c|}{ A. Aquaculture } \\
\hline $\begin{array}{l}\text { Florida } \\
\text { Aquaculture } \\
\text { Policy Act }\end{array}$ & 597 & $\begin{array}{l}\text { Creates state's aquaculture plan } \\
\text { to enhance the growth of } \\
\text { aquaculture in Florida while } \\
\text { protecting the environment. } \\
\text { Regulates shellfish leases by } \\
\text { qualified persons of any part of } \\
\text { the bottom, water column, or bed } \\
\text { of any water of the state for the } \\
\text { purpose of growing oysters or } \\
\text { clams (597.010), and Shellfish } \\
\text { Processors (597.020). }\end{array}$ & $\begin{array}{l}\text { Section } 373.1131 \text { simplifies permit } \\
\text { processing when more than one } \\
\text { agency requires aquaculture } \\
\text { permits. Other } 1996 \text { changes ease } \\
\text { regulatory burden on aquaculture } \\
\text { operations (see Laws of Florida, } \\
\text { 96-247). Also see leasing of } \\
\text { submerged Florida land for } \\
\text { aquaculture (253.69-253.75); } \\
\text { control of aquatic weeds, including } \\
\text { invasive nonnative weeds } \\
\text { (369.20-369.251); and theft of } \\
\text { aquaculture species (812.014(c)(7)). }\end{array}$ & $\begin{array}{l}\text { BSA } \\
\text { DACS }\end{array}$ \\
\hline \multicolumn{5}{|c|}{ B. Citrus Production } \\
\hline $\begin{array}{l}\text { Florida Citrus } \\
\text { Code }\end{array}$ & 601 & $\begin{array}{l}\text { Describes laws designed to } \\
\text { promote stable Florida citrus } \\
\text { industry. Covers production and } \\
\text { marketing topics ranging from } \\
\text { general prohibition of arsenic } \\
\text { use to advertising, inspection, } \\
\text { standards, marketing, and } \\
\text { processing of fruit. First person } \\
\text { processing orange or grapefruit } \\
\text { products and storing or removing } \\
\text { such processed citrus products } \\
\text { (except for direct consumption } \\
\text { by consumers) is subject to } \\
\text { excise tax (601.155). }\end{array}$ & $\begin{array}{l}\text { See } 2005-6 \text {, section } 2 \text {, amending } \\
601.04 \text {, establishing four (not three) } \\
\text { citrus districts. See } 2006-45, \\
\text { amending } 601.15 \text { so that excise tax } \\
\text { rates are at the maximum rate. See } \\
\text { restrictions on importing citrus } \\
\text { plants and stock from outside } \\
\text { Florida (581.182); restrictions on } \\
\text { new citrus varieties ([581.183); } \\
\text { exemption for alcohol beverage } \\
\text { manufacture from citrus in dry } \\
\text { counties (561.43). }\end{array}$ & $\begin{array}{l}\text { CIT } \\
\text { DACS }\end{array}$ \\
\hline $\begin{array}{l}\text { Laws } \\
\text { regulating } \\
\text { emissions from } \\
\text { citrus juice } \\
\text { processing } \\
\text { plants }\end{array}$ & 403.08725 & $\begin{array}{l}\text { Revises and conforms statutory } \\
\text { deadlines to the U.S. EPA } \\
\text { approval process and schedules. }\end{array}$ & $\begin{array}{l}\text { Sets limitations on sulfur content in } \\
\text { fuel used by citrus processors and } \\
\text { authorizes the FL DEP to develop } \\
\text { best management practices for } \\
\text { Clean Air Act pollutants not } \\
\text { otherwise regulated by the section. }\end{array}$ & $\begin{array}{l}\text { DACS } \\
\text { DEP }\end{array}$ \\
\hline \multicolumn{5}{|c|}{ C. Cotton / Fiber Production } \\
\hline $\begin{array}{l}\text { Florida Boll } \\
\text { Weevil } \\
\text { Eradication Law }\end{array}$ & $\begin{array}{l}593.101- \\
593.117\end{array}$ & $\begin{array}{l}\text { Gives the state the authority to } \\
\text { require cotton growers to supply } \\
\text { crop information, to declare a } \\
\text { quarantine of any area affected } \\
\text { by boll weevil, to establish and } \\
\text { control eradication zones, and to } \\
\text { destroy cotton not being grown } \\
\text { in accordance with this law. }\end{array}$ & $\begin{array}{l}\text { Authorizes rules for record keeping } \\
\text { of cotton shipments (593.107) and } \\
\text { penalties for violating declared } \\
\text { quarantine area (593.116). Restricts } \\
\text { movements of livestock, humans, } \\
\text { and honeybee colonies into or from } \\
\text { quarantine areas (593.11). Provides } \\
\text { assessments of up to } \$ 35 \text { per acre } \\
\text { to defray expenses related to } \\
\text { eradication or suppression } \\
\text { programs (593.114). }\end{array}$ & $\begin{array}{l}\text { DACS } \\
\text { DPI }\end{array}$ \\
\hline
\end{tabular}




\begin{tabular}{|c|c|c|c|c|}
\hline \multicolumn{5}{|c|}{ III. Florida Agricultural Laws: Crops and Products } \\
\hline $\begin{array}{l}\text { Statute / Law } \\
\text { (description) }\end{array}$ & $\begin{array}{l}\text { Florida } \\
\text { Statute } \\
\text { Number }\end{array}$ & General Description & $\begin{array}{l}\text { Related References, Details, } \\
\text { and Exceptions }\end{array}$ & $\begin{array}{l}\text { Primary } \\
\text { Contact } \\
\text { Agencies }\end{array}$ \\
\hline \multicolumn{5}{|c|}{ D. Forestry / Silviculture } \\
\hline $\begin{array}{l}\text { Laws regarding } \\
\text { general forestry }\end{array}$ & 589 & $\begin{array}{l}\text { Establishes Florida Forestry } \\
\text { Council, provides for uses of } \\
\text { state forests, and provides that } \\
\text { the Division of Forestry shall } \\
\text { administer tree planting } \\
\text { programs to assist rural } \\
\text { landowners and urban } \\
\text { communities. Gives broad } \\
\text { powers to the Division of } \\
\text { Forestry to prevent, detect, } \\
\text { suppress, and extinguish } \\
\text { wildfires wherever they may } \\
\text { occur on public or private land. }\end{array}$ & $\begin{array}{l}\text { Forest Protection (590) and Forest } \\
\text { Development (591) are related } \\
\text { bodies of laws. Allows Florida } \\
\text { Commissioner of Agriculture to } \\
\text { declare "severe drought } \\
\text { emergency" and prohibit any } \\
\text { burning within emergency area. } \\
\text { Authorizes continued use of } \\
\text { prescribed burning to control } \\
\text { amount of highly flammable } \\
\text { underbrush and dead plant material } \\
\text { to reduce the risk and severity of } \\
\text { wildfire. Provides requirements that } \\
\text { must be met to openly burn } \\
\text { land-clearing debris (590.125). }\end{array}$ & $\begin{array}{l}\text { DACS } \\
\text { FOR }\end{array}$ \\
\hline $\begin{array}{l}\text { Laws regarding } \\
\text { forest protection }\end{array}$ & 590 & $\begin{array}{l}\text { Gives broad powers to Division } \\
\text { of Forestry to monitor, control, } \\
\text { and extinguish fires. Prescribed } \\
\text { Burning Act (590.026) } \\
\text { authorizes and promotes the } \\
\text { continued use of prescribed } \\
\text { burning for ecological, } \\
\text { silvicultural, wildlife } \\
\text { management, and range } \\
\text { management purposes. }\end{array}$ & $\begin{array}{l}\text { Section } 590.026 \text { allows controlled } \\
\text { burning as a management practice, } \\
\text { but subject to rules of Division of } \\
\text { Forestry. Prohibits several forms of } \\
\text { unlawful burning ( } 590.10-590.12) \text {. } \\
\text { Anyone found to be in violation may } \\
\text { be convicted of a second degree or } \\
\text { first degree misdemeanor ( } 590.10 \text {; } \\
590.11) \text {. Requires permit to sell } \\
\text { cypress products ( } 590.50) \text {. Prohibits } \\
\text { fires without written permit near } \\
\text { protected areas during emergency } \\
\text { drought conditions (590.81). }\end{array}$ & $\begin{array}{l}\text { DACS } \\
\text { FOR }\end{array}$ \\
\hline $\begin{array}{l}\text { Florida } \\
\text { Community } \\
\text { Forest Law }\end{array}$ & $\begin{array}{l}591.16- \\
591.26\end{array}$ & $\begin{array}{l}\text { Provides mechanisms for } \\
\text { communities to acquire, } \\
\text { develop, and use forests or } \\
\text { lands suitable for forest } \\
\text { development. }\end{array}$ & $\begin{array}{l}\text { Encourages communities to } \\
\text { develop areas in local forests for } \\
\text { recreation and education. }\end{array}$ & $\begin{array}{l}\text { DACS } \\
\text { FOR }\end{array}$ \\
\hline \multicolumn{5}{|c|}{ E. Honey Certification and Honeybees } \\
\hline $\begin{array}{l}\text { Florida Honey } \\
\text { Certification } \\
\text { and Honeybee } \\
\text { Law }\end{array}$ & 586 & $\begin{array}{l}\text { Authorizes DACS to enforce } \\
\text { laws, make rules, and act to } \\
\text { keep honeybee pests and } \\
\text { unwanted bee races from } \\
\text { entering Florida, and to control } \\
\text { bee diseases by inspection, } \\
\text { quarantine and destruction of } \\
\text { hives. }\end{array}$ & $\begin{array}{l}\text { Compensates resident beekeepers } \\
\text { for equipment and hives destroyed } \\
\text { to eradicate American foulbrood } \\
\text { (586.14), but does not compensate } \\
\text { them for destruction due to } \\
\text { unwanted bee races or other } \\
\text { honeybee pests when these } \\
\text { problems cannot be otherwise } \\
\text { treated }(586.13(2)) \text {. }\end{array}$ & $\begin{array}{l}\text { API } \\
\text { DACS }\end{array}$ \\
\hline
\end{tabular}




\begin{tabular}{|c|c|c|c|c|}
\hline \multicolumn{5}{|c|}{ III. Florida Agricultural Laws: Crops and Products } \\
\hline $\begin{array}{l}\text { Statute / Law } \\
\text { (description) }\end{array}$ & $\begin{array}{l}\text { Florida } \\
\text { Statute } \\
\text { Number }\end{array}$ & General Description & $\begin{array}{l}\text { Related References, Details, } \\
\text { and Exceptions }\end{array}$ & $\begin{array}{l}\text { Primary } \\
\text { Contact } \\
\text { Agencies }\end{array}$ \\
\hline \multicolumn{5}{|c|}{ F. Nursery and Plant Industry } \\
\hline $\begin{array}{l}\text { Laws regarding } \\
\text { nursery plants }\end{array}$ & 581 & $\begin{array}{l}\text { Establishes laws governing } \\
\text { plant nurseries and the } \\
\text { movement and importation of } \\
\text { nursery stock from places } \\
\text { outside Florida. }\end{array}$ & $\begin{array}{l}\text { DACS can declare a plant pest, } \\
\text { noxious weed, or insect a nuisance, } \\
\text { and declare quarantines of affected } \\
\text { plants. Requires certificate of } \\
\text { registration from nursery operators } \\
\text { (581.131). See } 2006-45 \text {, section } 3 \text {, } \\
\text { establishing } 581.1843 \text {, imposing } \\
\text { additional restrictions on citrus } \\
\text { nursery stock propagation and } \\
\text { production (e.g., new citrus } \\
\text { nurseries must be set one mile back } \\
\text { from commercial citrus groves). See } \\
2005-210, \text { section } 19, \text { amending } \\
581.083 \text {, requiring special permit to } \\
\text { cultivate nonnative plants for } \\
\text { nonagricultural purposes exceeding } \\
\text { two acres; section } 18, \text { amending } \\
\text { 581.011, defining "invasive plant" as } \\
\text { a "naturalized plant that disrupts } \\
\text { naturally occurring native plant } \\
\text { communities. }\end{array}$ & $\begin{array}{l}\text { DACS } \\
\text { DPI }\end{array}$ \\
\hline \multicolumn{5}{|c|}{ G. Tropical Fruits } \\
\hline $\begin{array}{l}\text { Laws regarding } \\
\text { inspection of } \\
\text { fruits and } \\
\text { vegetables }\end{array}$ & $\begin{array}{l}603.11- \\
603.161\end{array}$ & $\begin{array}{l}\text { Provides for inspections, } \\
\text { inspection fees, enforcement of } \\
\text { Federal Marketing Agreement } \\
\text { for certain vegetables, maturity } \\
\text { standards for limes, and the } \\
\text { requirement to obtain and carry } \\
\text { sales receipt for certain tropical } \\
\text { and semitropical fruits. }\end{array}$ & & $\begin{array}{l}\text { DACS } \\
\text { FAV }\end{array}$ \\
\hline $\begin{array}{l}\text { Florida Tropical } \\
\text { Fruit Policy Act }\end{array}$ & $\begin{array}{l}603.201- \\
603.204\end{array}$ & $\begin{array}{l}\text { Establishes Tropical Fruit } \\
\text { Advisory Council, and calls for a } \\
\text { South Florida Tropical Fruit Plan } \\
\text { to encourage development of } \\
\text { tropical fruit production. }\end{array}$ & & $\begin{array}{l}\text { DACS } \\
\text { TFAC }\end{array}$ \\
\hline $\begin{array}{l}\text { Florida Tropical } \\
\text { or Subtropical } \\
\text { Fruit and } \\
\text { Vegetable } \\
\text { Sales Law }\end{array}$ & 570.55 & $\begin{array}{l}\text { Requires a buyer of } 55 \text { or more } \\
\text { pounds of tropical or subtropical } \\
\text { fruit and vegetables to demand } \\
\text { and carry a sales receipt from } \\
\text { seller. Sales receipt should } \\
\text { include the seller's driver's } \\
\text { license number or two other } \\
\text { forms of identification. Sales } \\
\text { receipt is to be kept for at least } \\
\text { one year. }\end{array}$ & $\begin{array}{l}\text { Violation may result in confiscation } \\
\text { and first degree misdemeanor. } \\
\text { Tropical or subtropical fruit is } \\
\text { defined broadly to mean fruit that } \\
\text { must be grown in tropical or } \\
\text { subtropical regions, except for citrus } \\
\text { fruit as defined in } 601.03(7) \text {. } \\
\text { Vegetables means tomatoes, } \\
\text { peppers, squash, cucumbers, leafy } \\
\text { greens, green beans, eggplant, } \\
\text { sweet corn, and cabbage. }\end{array}$ & DACS \\
\hline
\end{tabular}




\begin{tabular}{|c|c|}
\hline & Contact Agencies \\
\hline API & Burea of Plant and Apiary Inspection (DACS) \\
\hline BSA & Bureau of Seafood and Aquaculture (DACS) \\
\hline $\mathrm{CIT}$ & Department of Citrus \\
\hline DACS & Department of Agriculture and Consumer Services \\
\hline DEP & Department of Environmental Protection \\
\hline DPI & Division of Plant Industry \\
\hline FAV & Division of Fruit and Vegetables (DACS) \\
\hline FOR & Division of Forestry (DACS) \\
\hline TFAC & Tropical Fruit Advisory Council (DACS) \\
\hline $\begin{array}{l}\text { Bureau } \\
\text { Post O } \\
\text { Gaines } \\
\text { (352) } 3 \\
\text { http://w }\end{array}$ & $\begin{array}{l}\text { nd Apiary Inspection (API) } \\
47100 \\
614-7100 \\
154 \text { [voice] } \\
\text { state.fl.us/pi/plantinsp/paaisp.html }\end{array}$ \\
\hline $\begin{array}{l}\text { Bureau } \\
2051 \mathrm{E} \\
\text { Tallaha } \\
\text { (850) } 4 \\
\text { (850) } 9 \\
\text { http://w } \\
\text { http://w }\end{array}$ & $\begin{array}{l}\text { d and Aquaculture (BSA) } \\
\text { rive } \\
2310-3760 \\
\text { oice] } \\
\text { ax] } \\
\text { agriculture.com/seafood.htm } \\
\text { ood.com/ }\end{array}$ \\
\hline $\begin{array}{l}\text { Depart } \\
\text { Office } \\
\text { Post O } \\
\text { Lakelar } \\
\text { (863) } 4 \\
\text { (863) } 2 \\
\text { info@c } \\
\text { http://w }\end{array}$ & $\begin{array}{l}\text { rus (CIT) } \\
\text { utive Director } \\
48 \\
02 \\
\text { oice] } \\
\text { ax] } \\
\text { fl.us } \\
\text { uice.com }\end{array}$ \\
\hline $\begin{array}{l}\text { Florida } \\
\text { Office } \\
\text { The Ca } \\
\text { Tallaha } \\
\text { (850) } 4 \\
\text { (850) } 4 \\
\text { commis } \\
\text { http://w }\end{array}$ & $\begin{array}{l}\text { nt of Agriculture and Consumer Services (DACS) } \\
\text { missioner } \\
2399-0800 \\
\text { oice] } \\
\text { ax] } \\
\text { oacs.state.fl.us } \\
\text { state.fl.us/ }\end{array}$ \\
\hline $\begin{array}{l}\text { Florida } \\
3900 \text { C } \\
\text { Tallaha } \\
\text { (850) } 2 \\
\text { (850) } 2 \\
\text { http://w }\end{array}$ & $\begin{array}{l}\text { ht of Environmental Protection (DEP) } \\
\text { alth Boulevard } \\
2399 \\
\text { oice] } \\
\text { ate.fl.us/mainpage/default.htm }\end{array}$ \\
\hline & $\begin{array}{l}\text { Central District - Orlando } \\
\text { District Management } \\
3319 \text { Maguire Boulevard, Suite } 232 \\
\text { Orlando, FL } 32803 \\
\text { (407) 894-7555 [voice] } \\
\text { (407) 897-6499 [fax] } \\
\text { http://www.dep.state.fl.us/central/ }\end{array}$ \\
\hline
\end{tabular}




\begin{tabular}{|c|}
\hline Contact Agencies \\
\hline 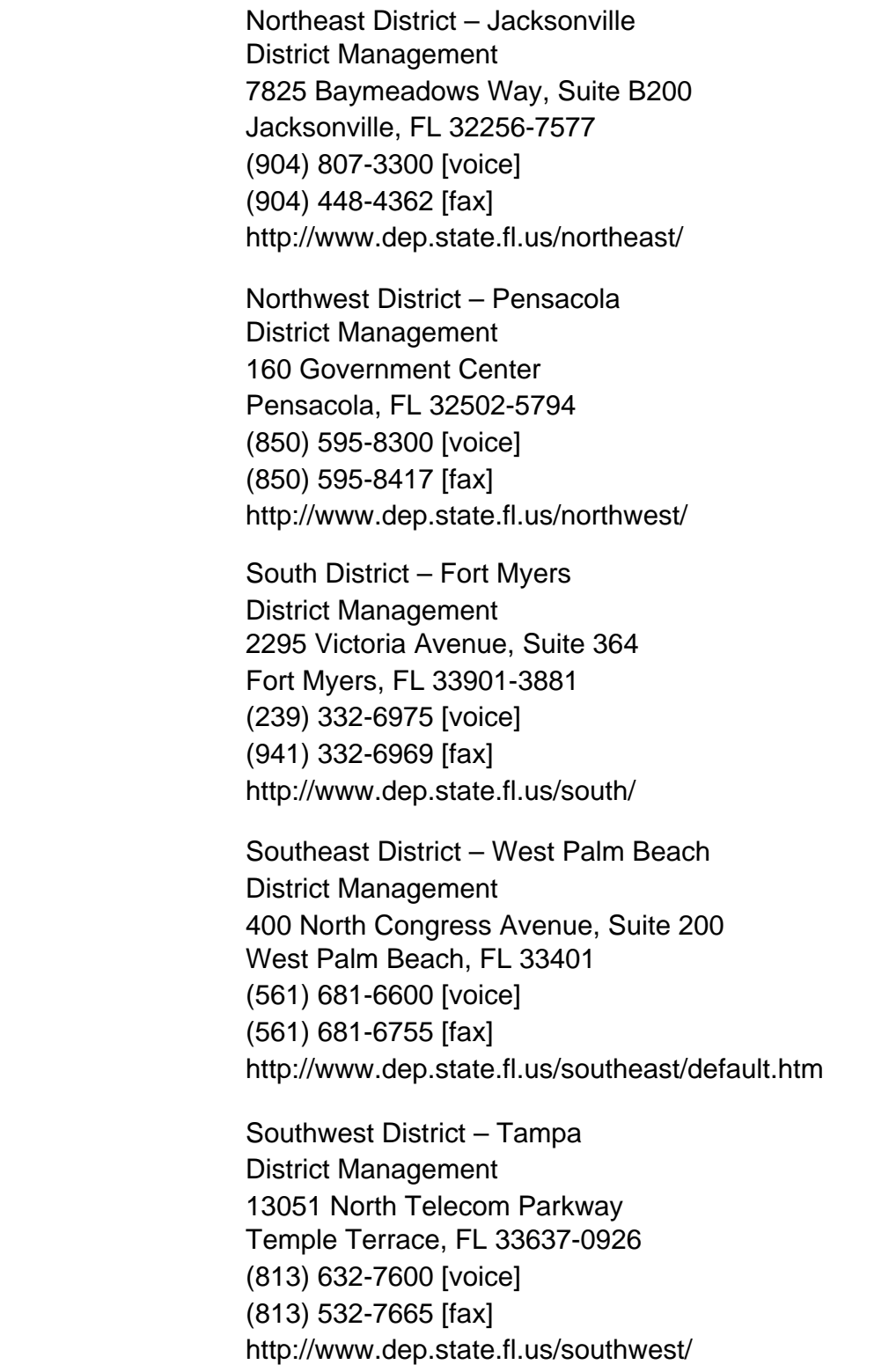 \\
\hline $\begin{array}{l}\text { Division of Plant Industry (DPI) } \\
\text { Post Office Box } 147100 \\
\text { Gainesville, FL } 32614-7100 \\
\text { (352) 372-3505 x106 [voice] } \\
\text { http://www.doacs.state.fl.us/pi/ }\end{array}$ \\
\hline $\begin{array}{l}\text { Division of Fruit and Vegetables (FAV) } \\
\text { Office of the Director } \\
500 \text { Third Street N.W. } \\
\text { Winter Haven, FL } 33881-3403 \\
\text { (863) 291-5820 [voice] } \\
\text { (863) 298-7860 [fax] } \\
\text { http://www.doacs.state.fl.us/fruits/ }\end{array}$ \\
\hline
\end{tabular}




\begin{tabular}{|l|}
\hline \hline \\
\hline Florida Division of Forestry (FOR) \\
Office of the Director \\
3125 Conner Boulevard \\
Tallahassee, FL 32399-1650 \\
(850) 488-4274 [voice] \\
(850) 488-0863 [fax] \\
dof_support@doacs.state.fl.us \\
http://www.fl-dof.com/ \\
\hline Tropical Fruit Advisory Council (TFAC) \\
Florida Department of Agriculture and Consumer Services (DACS) \\
Office of the Commissioner \\
The Capitol \\
Tallahassee, FL 32399-0800 \\
(850) 488-3022 [voice] \\
(850) 488-7585 [fax] \\
commissioner@doacs.state.fl.us \\
http://www.doacs.state.fl.us/ \\
\hline \hline
\end{tabular}

